\title{
Frequently Cited Works
}

Citations referencing both original and translated editions of a text indicate page numbers in the following format: original/translation. With the exception of Sein und Zeit and irregular volumes in English translation, my endnotes citing Heidegger refer to his texts according to their Gesamtausgabe number.

All 'GA' designations shall refer to Heidegger's Gesamtausgabe volumes.

EB Polt, Richard, The Emergency of Being: On Heidegger's Contributions to Philosophy (Ithaca, NY: Cornell University Press, 2006).

EH Capobianco, Richard, Engaging Heidegger (Toronto: University of Toronto Press, 2011).

FE Sheehan, Thomas, 'Facticity and Ereignis', in Interpreting Heidegger, ed. Daniel Dahlstrom (Cambridge: Cambridge University Press, 2011), 42-68.

GA65 Heidegger, Martin, Beiträge zur Philosophie (Vom Ereignis) (Frankfurt am Main: Klostermann, 2003), GA65. English: Contributions to Philosophy: Of the Event, trans. Richard Rojcewicz and Daniela Vallega-Neu (Bloomington: Indiana University Press, 2012). I abbreviate this text as GA65 in endnote citations and as Beiträge in in-text mentions.

GA71 Heidegger, Martin, Das Ereignis (Frankfurt am Main: Klostermann, 2009). English: The Event, trans. Richard Rojcewicz (Bloomington: Indiana University Press, 2013).

HCP Vallega-Neu, Daniela, Heidegger's Contributions to Philosophy (Bloomington: Indiana University Press, 2003). 
HWB Capobianco, Richard, Heidegger's Way of Being (Toronto: University of Toronto Press, 2014).

SZ Heidegger, Martin, Sein und Zeit (Tübingen: Max Niemeyer Verlag, 2006). English: Being and Time, trans. John Macquarrie and Edward Robinson (New York: Harper and Row, 1962).

WW Heidegger, Martin, 'Vom Wesen der Wahrheit', in [GA9] Wegmarken (Frankfurt am Main: Klostermann, 1976), 177-202. English: 'On the Essence of Truth', trans. John Sallis, in Pathmarks, ed. William McNeill (Cambridge: Cambridge University Press, 1998), 136-54.

Throughout, within quotations I shall use square brackets for my own insertions or to include original language terms. Parentheses within quotations are those present in the source text. 
For my wonderful mother, Arlette 
